\title{
Tumor-Associated Macrophages in Hematologic Malignancies: New Insights and Targeted Therapies
}

\author{
Amy J. Petty ${ }^{1,2}$ and Yiping Yang ${ }^{2, *}$ \\ 1 Department of Pharmacology and Cancer Biology, Duke University, Durham, NC 27710, USA; \\ amy.petty@duke.edu \\ 2 Division of Hematology, The Ohio State University Wexner Medical Center, 508 BRT, 460 W 12th Avenue, \\ Columbus, $\mathrm{OH} 43210, \mathrm{OH}$, USA \\ * Correspondence: yiping.yang2@osumc.edu; Tel.: +1-(614)-685-0643; Fax: +1-(614)-293-7526
}

Received: 6 November 2019; Accepted: 25 November 2019; Published: 27 November 2019

check for updates

\begin{abstract}
The growth of hematologic malignant cells can be facilitated by other non-tumor cells within the same microenvironment, including stromal, vascular, immune and mesenchymal stem cells. Macrophages are an integral part of the human innate immune system and the tumor microenvironment. Complex interplays between the malignant hematologic cells and the infiltrating macrophages promote the formation of leukemia, lymphoma or myeloma-associated macrophages. These pro-tumorigenic macrophages in turn play an important part in facilitating tumor growth, metastasis and chemotherapeutic resistance. Previous reports have highlighted the association between tumor-associated macrophages (TAMs) and disease progression in hematologic malignancies. This review summarizes the role of TAMs in different subtypes of leukemia, lymphoma and myeloma, focusing on new insights and targeted therapies.
\end{abstract}

Keywords: tumor-associated macrophage; nurse-like cells; leukemia; lymphoma; myeloma; immunotherapy

\section{Introduction}

In all stages of tumor development, various types of immune cells, including lymphocytes and macrophages coinhabit with malignant cells. The abundance of tumor infiltrating macrophages, termed tumor-associated macrophages (TAMs) in an array of solid tumors have been highlighted in previous reports [1]. As a critical component of the human innate immune system, it was originally thought that the presence of TAMs contributes to tumor surveillance and eradication. However, recent evidence suggests that TAMs are paradoxically involved in tumorigenesis and may contribute to neoplastic progression through a variety of mechanisms, including promoting angiogenesis, metastasis, cancer stemness and local immunosuppression within the tumor microenvironment (TME) [2,3]. Hence, TAM infiltration and its polarization to a pro-tumorigenic and immunosuppressive phenotype are correlated with poor prognosis in many types of human cancer [1].

Increasing evidence also underlined the important role TAMs play in hematologic malignancies [4,5]. Within the TME of leukemia, lymphoma or myeloma, there are dynamic interactions between immune cells, including TAMs and the malignant hematologic cells. Under the influence of tumor cells, these TAMs are then reprogrammed into an immunosuppressive and pro-tumorigenic phenotype, which can in turn subvert immune responses and contribute to accelerated tumorigenesis. This review focuses on recent discoveries on the role of TAMs in hematologic malignancies.

\section{Macrophages and Tumor-Associated Macrophages}

Macrophages are cells of the hematopoietic system that participate in many important functions in the body, ranging from inflammation, tissue repair to homeostasis [6]. As macrophages are highly 
responsive to their environmental stimuli, there is a great level of heterogeneity in macrophage morphology, phenotype and function. Activated macrophages have been divided into two broad categories-the classically activated M1 macrophages and the alternatively activated M2 macrophages [7]. Though these states mirror the T helper 1 (Th1)-Th2 states of T cells, the M1/M2 phenotypes are not stably differentiated states in the same way as Th1 and Th2 cells. Rather, macrophages can exhibit phenotypes in a spectrum of possible forms with two extremes defined by M1 and M2 [8]. M1 macrophages, activated by lipopolysaccharide (LPS), interferon- $\gamma$ (IFN- $\gamma$ ), granulocyte-macrophage colony stimulating factor (GM-CSF), preferentially secrete pro-inflammatory molecules, such as IL-1, IL-6, IL-12, tumor necrosis factor- $\alpha$ (TNF- $\alpha$ ), CXCL9, CXCL10, nitric oxide and reactive oxygen species. Due to their high capacity to antigen present and elicit a strong Th1 response, M1 macrophages are considered antitumoral. In contrast, M2 macrophages are activated by IL-4/IL-13, IL-10 and macrophage colony stimulating factor (M-CSF; also known as CSF1) and in turn express high levels of anti-inflammatory molecules, such as IL-10, transforming growth factor- $\beta$ (TGF- $\beta$ ), CCL17, CCL22, arginase, mannose (CD206) and scavenger (CD163) receptors. As such, M2 macrophages are thought to play an immunosuppressive role in the body [7-9].

The formation of pro-tumorigenic TAMs in the tumor stroma requires-1) factors that facilitate monocyte/macrophage recruitment and expansion; and 2) factors that drive the TAM polarization into the immunosuppressive phenotype [10]. Macrophage infiltration into the tumor stroma is mediated by chemokines CCL2, CCL5, CCL7 and CX3CL1 as well as molecules such as M-CSF and vascular endothelial growth factor (VEGF) [11-14]. Once recruited to the tumor site, various tumor-derived or stroma-derived factors orchestrate the immunosuppressive and pro-tumorigenic polarization of TAMs $[15,16]$. IL-4 and IL-13 act on TAMs through intracellular signal transducer and activator of transcription 6 (Stat6) and PI3K signaling while IL-10 produced by regulatory T cells $\left(\mathrm{T}_{\text {reg }}\right.$ ) also promotes the TAM phenotype via the actions of Stat3 [17]. Other molecules secreted by the tumor cells, including TGF- $\beta$, lactic acid and sonic hedgehog (Shh) also strongly promote M2-polarization of TAMs, resulting in subsequent promotion of tumorigenesis [18-20]. It is important to note that TAMs are a group of highly heterogeneous cells that have diverse functions and phenotypes depending on cancer type and tumor stage. In addition to classifying TAMs based on previously described M2-macrophage markers, recent attempts to categorize TAMs based on their functional role in the tumor microenvironment have also gained momentum [1]. Therefore, the M1-M2 dichotomy is excessively simplistic for TAM classification and additional studies are needed to better clarify TAM classification and subgroups within the TME of different cancer types.

The presence of macrophages in the TME of leukemia, lymphoma or myeloma can be suggestive of several signs, including prognosis of disease progression and efficacy of chemotherapy. Once in the TME, TAMs can interact with other cells through different mechanisms to create a pro-tumorigenic environment-1) stimulate tumor cell growth and metastasis directly by producing growth and matrix remodeling factors; 2) promote chemoresistance in cancer cells and 3) induce immunosuppression by altering the behavior of innate or adaptive immune cells [21]. Due to its critical role in the TME, its role in solid tumors has been extensively investigated. However, due to the unique and diverse microenvironments involved in hematologic malignancies, the importance of TAMs only began to emerge. We will focus on recent preclinical and clinical discoveries.

\section{The Role of TAMs in Leukemia}

Recent publications have emphasized the role of TAMs in three subtypes of leukemia, including acute lymphoblastic leukemia (ALL), acute myeloid leukemia (AML) and chronic lymphocytic leukemia (CLL).

\subsection{Acute Lymphoblastic Leukemia}

Evaluating the phenotype of $\mathrm{CD}_{163^{+}}$M2-like TAMs in 58 acute T-lymphoblastic leukemia (T-ALL) patients revealed that higher numbers of $\mathrm{CD}_{163}{ }^{+}$cells were correlated with poor prognosis. 
In addition, the percentage of $\mathrm{CD} 163^{+}$cells was an independent prognostic factor in these patients. Co-culturing M2-macrophages with T-ALL cell in vitro significantly induced leukemic cell proliferation via $\mathrm{C} 5 \mathrm{a}, \mathrm{TNF} \alpha$, growth-related oncogene (GRO)- $\alpha$ and IL-6 [22]. Hohtari et al. analyzed immune cell constitution in adult precursor B cell ALL bone marrow (BM), demonstrating increased proportion of M2-like macrophages and myeloid-derived suppressor cells (MDSCs) in ALL patients' BM compared to healthy patients [23].

Further analysis of different lymphoid organs in a Notch1-overexpressing T-ALL mouse model revealed different phenotypes and gene expression patterns of TAMs in BM vs. spleen. Though both capable of expressing M2-associated genes, splenic TAMs stimulated the proliferation of T-ALL cells more potently compared to BM-TAMs, demonstrating the highly plastic nature of TAMs under different microenvironments [24]. Valencia et al. also reported that ALL cells released Bone Morphogenetic Protein 4 (BMP4) to induce immunosuppressive dendritic cells and generate M2-like macrophages, which produced low TNF $\alpha$ and high CCL2, IL-6 and IL-10 [25]. Lastly, a recent report found that stromal interaction molecule 1 (STIM1) and STIM2 mediated the pathologic cancer-induced inflammation in the TME of T-cell ALL. Deletion Stim1 and Stim2 in malignant ALL cells not only reduced the number of infiltrating macrophages but also rescued the pro-inflammatory phenotype of TAMs through IFN $\gamma$ [26]. Together, these reports highlighted that interactions between leukemic cells and TAMs may be important in promoting tumorigenesis in ALL.

\subsection{Acute Myeloid Leukemia}

Al-Matary et al. evaluated the role of TAMs in AML tumorigenesis and found that the frequency of $\mathrm{CD}_{163}{ }^{+} \mathrm{CD} 206^{+}$M2-like TAMs was significantly elevated in the BM of AML patients compared to healthy volunteers. Using different murine models of AML, they also found that leukemic cells polarized TAMs to an M2-like phenotype, which subsequently accumulated in the BM and spleen of tumor-bearing mice. Conversely, bone marrow-derived macrophages (BMDMs) from leukemic mice supported the in vitro expansion of AML cells better than that from non-leukemic mice. They also discovered the critical role of growth factor independent 1 (Gfi1) transcriptional repressor in polarizing TAMs toward a pro-tumorigenic M2-state in vitro and in vivo [27]. Yang et al. further confirmed that the number of $\mathrm{CD} 163^{+}$M2-like TAMs was correlated with worse prognosis in AML patients with splenic TAMs exhibiting more M2-characteristics than BM-TAMs. Additionally, they found that Interferon Regulatory Factor 7 (IRF7) contributed to the M1-polarization of TAMs through activation of the SAPK/JNK pathway and subsequent activation of the IRF7-SAPK/JNK pathway resulted in more M1-like TAMs, which was correlated with prolonged survival in leukemic mice [28].

Lastly, a recent report by Jiang et al. highlighted the role of monocytic leukemia zinc-finger protein (MOZ) in the differentiation and M1-polarization of macrophages in AML. A low level of MOZ was associated with poor prognosis in AML patients and genetic silencing of MOZ suppressed M1 activation of macrophages. Furthermore, miR-223, a microRNA that was previously shown to suppress M1-polarization and play an important role in the pathogenesis of AML can regulate MOZ functions [29]. Collectively, these reports provided some evidence for the importance role M2-like TAMs play in the progression of AML.

\subsection{Chronic Lymphocytic Leukemia}

The role macrophages play in CLL was first discovered in 2000 when Burger et al. found that differentiated peripheral mononuclear cells from B-cell CLL patients could protect CLL cells from undergoing spontaneous apoptosis through the action of stromal cell-derived factor-1 (SDF-1; also known as CXCL12) in vitro and the authors coined the term "nurse-like cells" (NLCs) [30]. CXCL13 can also be released by the $\mathrm{CD} 68^{+} \mathrm{NLC}$ s to support CLL migration and growth through the activation of p44/42 mitogen-activated protein kinases (MAPKs) downstream of CXCR5 [31]. It was later discovered that NLCs were a critical component of the leukemic microenvironment in CLL and phenotypically and functionally equivalent to TAMs in solid tumors with high expressions of CD11b, CD68 and 
CD163 [32,33]. Additionally, under the influence of the hepatocyte growth factor (HGF) released by leukemic cells, c-Met ${ }^{+}$NLCs exhibited the immunosuppressive functions of M2-like TAMs by inhibiting T-cell proliferation through the action of TGF- $\beta$, IL-10 and indoleamine 2,3-idoxygenase (IDO) and supporting Foxp $3^{+} \mathrm{T}$ regulatory $\left(\mathrm{T}_{\text {reg }}\right.$ ) cell expansion [34]. Using the E $\mu$-TCL1 mouse model of CLL, Hanna et al. found that macrophages accumulated in the peritoneal cavity and spleen of leukemic mice in a CCR2-dependent manner and exhibited the M2-like phenotype with a high expression of Programmed Death Ligand-1 (PD-L1). Depletion of myeloid cells in CLL mice using liposomal Clodronate resulted in reduced tumorigenesis and repaired the activation of $\mathrm{T}$ cells, demonstrating the extensive immunosuppressive functions of M2-like TAMs in CLL [35].

Examination of cross-talks between the leukemic cells and TAMs revealed that CLL cells could release nicotinamide phosphoribosyltransferase (NAMPT) to induce the M2-phenotype in TAMs through the actions of Stat 3 and NF-KB signaling. These CD163 ${ }^{\text {hi }} \mathrm{CD} 206^{\text {hi }}$ macrophages expressed IDO, IL-10. CCL18, IL-6 and IL-8 to support leukemic growth and suppress effector cell responses [36]. Galletti et al. also found that leukemic cells induced the M2-polarization of TAMs in CLL through the colony-stimulating factor 1 (CSF1)-CSF1R pathway and targeting of macrophages by CSF1R blockade reduced leukemic cell load in the BM and prolonged survival [37]. Spontaneously dying CLL cells may also release high-mobility group box 1 (HMGB1) protein to promote the differentiation of monocytes into NLCs/TAMs. Coincidently, the presence of HMGB1 protein and DNA in patient plasma was positively correlated with tumor burden and adverse clinical outcome [38]. Lastly, CLL cells were found to release CCL3 and CCL4 as a result of B-cell receptor (BCR) stimulation by TAMs and the two chemokines worked to recruit other leukemic cells or macrophages to the tumor site [39]. Together, these reports suggested that targeting TAMs in CLL might be therapeutically efficacious. Indeed, simply reprogramming TAMs toward an M1-phenotype with IFN- $\gamma$ enhanced Fc $\gamma$ R-mediated production of cytokines and rituximab-mediated phagocytosis of CLL cells in vitro [40]. Eliminating both offending parties by co-targeting of TAMs and CD $20^{+}$leukemic cells with blocking antibodies helped reprogram the tumor microenvironment and conferred a synergistic survival benefit in the mouse model [37].

Collectively, this further establishes the important role of macrophages in the tumorigenesis of leukemia and suggests that therapies targeting the leukemia-macrophage interactions could be highly effective clinically. However, further investigation is needed to investigate the diverse molecular mechanisms of TAMs in distinct microenvironments of different types of leukemia.

\section{The Role of TAMs in Lymphoma}

Similar to the role of TAMs in leukemia, macrophages are a critical inducer of lymphoma progression, both in classic Hodgkin's lymphoma (CHL) and non-Hodgkin's lymphoma (NHL).

\subsection{Classic Hodgkin's Lymphoma}

The TME of CHL is composed of mainly inflammatory immune cells and only a small percentage of the cells, approximately $1 \%$ are malignant Hodgkin Reed-Sternberg (HRS) cells [41]. Thus, the role played by macrophages is especially important in the pathogenesis of CHL. A study by Steidl et al. demonstrated that increased number of CD68 $8^{+}$TAMs in lymph nodes was strongly correlated with decreased progression-free survival (PFS) and more frequent relapse after autologous hematopoietic cell transplantation in CHL patients [42]. Evaluation of CD163, an M2-marker in patient samples of advanced $\mathrm{CHL}$ showed that $\mathrm{CD} 68^{+} \mathrm{CD} 163^{+}$TAMs were correlated with inferior overall survival [43]. In addition, the percentage of CSF1R ${ }^{+}$TAM was also inversely associated with survival in CHL patients [44]. A meta-analysis by Guo et al. further confirmed that a higher density of $\mathrm{CD}^{+} 8^{+}$or CD163+ TAMs was a strong predictor of clinical outcome in patients with CHL [45].

In addition, the majority of PD-L1 expression in the TME of CHL was contributed by TAMs. These PD-L1 ${ }^{+}$macrophages colocalized with PD-L1 ${ }^{+}$HRS cells and were in close contact with PD-1 ${ }^{+} \mathrm{T}$ cells [46]. Lastly, Vari et al. showed that PD-L1/PD-L2 ${ }^{+}$TAMs could suppress activation of PD- $1^{\text {hi }}$ 
natural killer (NK) cells, a process that can be reversed by PD-1 blockade. As a result, depletion of circulating monocytes from the blood of pretherapy patients with $\mathrm{CHL}$ enhanced $\mathrm{CD} 3^{-} \mathrm{CD} 56^{\mathrm{hi}} \mathrm{CD} 16^{-}$ NK activation, suggesting a critical role for TAMs in immune evasion and subsequently progression of CHL [47]. Though mechanistic evidence focused on the signaling events within TAMs is lacking, new reports have highlighted the effects of PI3K inhibition on macrophage M2-polarization and metabolic switch in CHL, suggesting the PI3K-Akt pathway could play an important role in TAMs within the TME of Hodgkin's lymphoma [48]. More research is needed to investigate how CHL cells and the surrounding environment drive the immunosuppressive M2-polarization of TAMs.

\subsection{Non-Hodgkin's Lymphoma}

The prognostic value of TAMs in follicular lymphoma (FL) was demonstrated in two early reports, which showed that increased $\mathrm{CD} 68^{+}$TAM count was associated with poor survival in FL patients $[49,50]$. This was proposed to be associated with M2 polarization of macrophages. Indeed, literatures also showed that increased microvascular density and angiogenic sprouting were positively correlated with increased $\mathrm{CD}_{163^{+}}$TAMs and poor outcome in FL [51]. This polarization of TAMs can be directly induced by apoptotic lymphoma cells and M2-TAMs expressed decreased level of galectin-3, a pleiotropic glycoprotein involved in apoptotic cell clearance, ultimately resulting in more aggressive progression of NHL [52]. Additionally, mesenchymal stromal cells (MSCs) in the BM of FL overexpressing CCL2 can also participate in driving macrophage toward a pro-angiogenic and immunosuppressive M2-phenotype [53]. In turn, these immunosuppressive macrophages can trans-present IL-15 through a $\mathrm{T}$ cell-derived CD40L-dependent mechanism to induce proliferation of follicular lymphoma cells [54].

In human diffuse large B cell lymphoma (DLBCL), though the first-line chemotherapeutic regimen including cyclophosphamide, doxorubicin, vincristine and prednisone (CHOP) is fairly successful in terms of remission rate, it is often followed by a relapse rate of $40 \%$ within 2-3 years [21]. As inflammatory response gene signatures in the TME are defining features of DLBCL, studies also found a strong correlation between these inflammatory signals and poor prognosis or treatment resistance in patients with DLBCL $[55,56]$. It was found that one of two TME signatures, stromal-2 contained signature genes encoded for well-known markers of TAMs and MDSCs and can predict clinical outcomes in DLBCL patients $[55,57,58]$. Other reports confirmed the prognostic value of TAMs by showing that increased TAMs or M2-TAMs was related to worse prognosis and poorer clinical outcomes in DLBCL and DLBCL of the central nervous system [59-62]. In addition, the presence of $\mathrm{CD}_{2} 4^{+}$macrophages was associated with a higher relapse rate and poorer survival in malignant lymphoma patients treated with allogeneic hematopoietic stem cell transplantation [63]. The immunosuppressive CD14 ${ }^{+} \mathrm{HLA}-\mathrm{DR}{ }^{\text {low } /-} \mathrm{CD} 120 \mathrm{~b}^{\text {low }}$ monocytes/macrophages can suppress $\mathrm{T}$ cell proliferation through the overexpression of Arg-1, a marker for M2 TAMs and an enzyme that depletes essential nutrients for $\mathrm{T}$ lymphocytes. In addition, these macrophages had decreased Stat1 phosphorylation, a transcription factor that has been proposed to modulate M1-polarization of TAMs $[8,64]$. The expansion of this population of cells was later shown to be induced by IL-10 [65]. Lastly, M2-TAMs can directly remodel the extracellular matrix in DLBCL through legumain, an asparaginyl endopeptidase that leads to degradation of fibronectin and collagen I and increased angiogenesis. Inhibiting legumain action led to decreased tumor growth in a xenograft DLBCL model with reduced angiogenesis and collagen deposition in the TME [66]. Taken together, these reports indicated the active role TAMs play in the progression of DLBCL.

In summary, these reports highlighted the complex interactions between lymphoma cells and TAMs within the microenvironment. Further analysis is needed to investigate the underlying how lymphoma cells drive the phenotypic and functional shift seen in TAMs to better inform future therapeutic developments. 


\section{The Role of TAMs in Myeloma}

TAMs were also found to play a critical role in multiple myeloma (MM), a malignant B-cell cancer involving the uncontrolled growth of plasma cells in the BM. In an early study, Zheng et al. found that $\mathrm{CD}^{+} 8^{+}$macrophages heavily infiltrated the BM of MM patients compared to healthy controls. These macrophages supported proliferation and suppressed apoptosis of myeloma cells in the presence of chemotherapy by inhibiting activation and cleavage of caspase- 3 and poly-ADP ribose polymerase (PARP) and maintaining the levels of Bcl-xL in vitro [67]. In addition, macrophages, working in conjunction with MSCs were found to support the proliferation and survival of MM cells through IL-6 and IL-10 production [68]. An in vivo evidence emerged in 2013 where Zheng et al. showed that TAMs contributed to myeloma drug resistance through P-selectin glycoprotein ligand-1 (PSGL-1)/selectins and intercellular adhesion molecule-1 (ICAM-1)/CD18 contact-dependent interactions. These interactions between infiltrating TAMs and myeloma cells resulted in activation of non-receptor tyrosine kinase Src, Erk1/2 kinases and c-myc activation in MM cells, all of which have been shown to promote MM cell survival and drug resistance $[69,70]$. Together, these reports provided early evidence for the important role TAMs play in MM tumor progression. The prognostic value of $\mathrm{CD} 68^{+} \mathrm{CD} 163^{+}$TAMs in MM was realized when Suyani et al. found that number of TAMs was associated with high-grade micro-vessel density and decreased survival [71]. Two reports further reported a negative correlation between CD163 and CD206 expressions, two M2-macrophage markers and overall survival in patients with MM [72,73]. Recently, high number of CD163 ${ }^{+}$TAMs was also correlated with poor prognosis characterized by decreased PFS and complete remission/near-complete remission in MM patients receiving bortezomib-based chemotherapy [74]. Collectively, there is strong literature evidence demonstrating the close relationship between TAMs and MM. However, there is no report demonstrating the intracellular events occurring in TAMs as a result of these interactions. Potential therapeutic strategies should also be explored to better target macrophages in treatment of MM.

\section{New Macrophage-Targeting Therapies in Hematologic Malignancies}

Many clinical approaches to therapeutically target TAMs are currently under investigation. To prevent immunosuppression and tumor-promotion mediated by mainly M2-macrophages, three general approaches are currently believed to be effective-depletion, reprogramming and molecular targeting. This review will focus on some of the recent developments in macrophage-targeting therapies in hematologic malignancies.

It is well known that CSF1R signaling in macrophages is essential for its recruitment, differentiation and survival. The loss of CSF1-CSF1R signaling can significantly reduce the number of TAMs in mouse models of various solid tumors [10]. Therefore, it was proposed that blockade of CSF1R can reduce macrophage accumulation and decrease its immunosuppressive functions. Indeed, in B-cell CLL, CSF1R inhibition with a JAK2/FLT3 inhibitor, pacritinib was associated with significant depletion of TAMs and consequently inhibited leukemic cell survival [75]. A similar effect was recently observed in AML where CSF1R inhibition reduced paracrine growth signals from the TME, resulting in reduced leukemic cell viability [76]. In MM, blocking CSF1R with antibody or depleting macrophages both led to reduced tumor growth and sensitized myeloma cells to chemotherapy in vivo [77]. The antitumoral effects of CSF1 blockade was also observed in mantle cell lymphoma where treatments with GW2580, a CSF1R inhibitor reduced lymphoma cell survival, irrespective of their sensitivity to ibrutinib, a Bruton's tyrosine kinase (BTK) inhibitor [78]. Lastly, synergistic effects were observed when combining CSF1R inhibitors with idelalisib or ibrutinib, two current CLL therapies that target PI3K and BTK, respectively [79]. Together, these reports highlighted the therapeutic potential of CSF1R blockade in treatments of leukemia or lymphoma, but further investigation is needed in the clinical setting to better define its role.

Other agents that target the CCL2 pathway include trabectedin and lenalidomide. Trabectedin can selectively kill monocytes and/or macrophages by inhibiting CCL2, CXCL8, IL-6 and VEGF production 
in vitro [80]. Trabectedin treatment resulted in selective killing of monocytes/macrophages in blood, spleen and tumors while sparing neutrophils and lymphocytes via a caspase-8-dependent apoptosis pathway. This was also associated with downregulation of CCL2 and VEGF, resulting marked decrease in the recruitment of TAMs to the TME and reduced angiogenic sprouting in vivo [81]. While trabectedin is currently approved for the treatment of soft tissue sarcoma and relapsed platinum-sensitive ovarian cancer in the US, its potential role has been proposed in MM [82]. Due to its ability to functionally reshape macrophages and TAMs, its role should be further investigated in other macrophage-rich hematologic malignancies.

The use of lenalidomide, an immunomodulatory agent has been implicated in B-cell malignancies including CLL and MM. Though the exact mechanism of lenalidomide's antitumor activity is not completely understood, it has been reported to downregulate anti-inflammatory and proangiogenic cytokines and modify the TME via promotion of T and NK cell functions [83]. An early study showed lenalidomide suppressed the secretion CCL2 from NLCs and inhibited the survival support of NLCs for CLL cells in vitro [84]. A recent in vivo study showed that lenalidomide in combination with dendritic cell vaccination and anti-PD-1 blocking antibody decreased M2-TAMs with an associated reduction in TGF- $\beta$ and IL-10 in the spleen of myeloma-bearing mice [85]. In several clinical trials for B-cell lymphoma, lenalidomide showed promising clinical efficacy either as a single agent or in combination with other immunotherapeutic agents [86-89]. Together, this provided exciting evidence for the unique immunomodulatory properties in leukemia and lymphoma. Further investigation should focus on elucidating its mechanism of action in the TME and better defining its role in additional clinical settings.

One exciting new approach to target macrophages in leukemic or lymphoid malignancies involves targeting the CD47 molecule, a surface glycoprotein that is commonly expressed on malignant cells. When bound to its receptor signal regulatory protein alpha (SIRP $\alpha)$ on myeloid cells, it inhibits macrophage phagocytosis and allows for evasion of innate immune surveillance [90]. Early studies have demonstrated increased CD47 expression on dysplastic human hematopoietic cells, especially in AML and CLL [91,92]. Preclinical evidence showed that blockade of CD47 promoted macrophage phagocytosis to inhibit growth of myeloma cells and triggered $\mathrm{T}$ cell-mediated destruction of tumors through increased dendritic-cell cross-priming [93,94]. In addition, a bispecific antibody with affinity for both CD47 and CD20 recapitulated the synergistic effect of rituximab plus anti-CD47 antibody in vitro and led to significantly prolonged survival in mouse models of NHL [95]. Together, these reports paved the way for exploring the therapeutic potential of targeting CD47 in clinical settings. Several CD47-SIRP $\alpha$ antagonists are currently active in phase I o I/II clinical trials for hematologic malignancies-including Hu5F9-G4, CC-90002, TTI-621 and ALX-148 (Table 1). The first two agents, Hu5F9-G4 and CC-90002 are humanized monoclonal antibodies against CD47 while TTI-621 and ALX-148 are SIRP $\alpha$-IgGFc fusion proteins that act as decoy receptors [96]. Hu5F9-G4 in combination with rituximab showed promising therapeutic efficacy in a phase $1 \mathrm{~b}$ trial for patients with DLBCL and FL with $50 \%$ of the patients enrolled showed objective complete or partial response [97]. As part of a phase 1a trial, five patients with Sezary syndrome, the leukemic variant of cutaneous T-cell lymphoma were treated with TTI-621. Treatment resulted in significant tumor load reduction and skin improvement [98]. Overall, the use of CD47-targeting therapies in clinical settings has an exciting outlook and more comprehensive analysis of its effects on macrophages and other innate or adaptive immune cells needs to be conducted. 
Table 1. CD47 antagonists currently in clinical trials for hematologic malignancies.

\begin{tabular}{|c|c|c|c|c|}
\hline Agents & Diseases & Open Clinical Trials & Phase & Status and Results \\
\hline Hu5F9-G4 & AML & $\begin{array}{l}\text { NCT026783338-CAMELLIA: anti-CD47 } \\
\text { antibody therapy in relapsed/refractory AML }\end{array}$ & I & $\begin{array}{l}\text { - Recruitment completed } \\
\text { - Hu5F9-G4 infusion in refractory } \\
\text { AML patients led to hemoglobin } \\
\text { decline and increased transfusion } \\
\text { requirements [99]. }\end{array}$ \\
\hline Hu5F9-G4 + Atezolizumab & AML & $\begin{array}{l}\text { NCT03922477-trial of Hu5F9-G4 with } \\
\text { atezolizumab in patients with relapsed and/or } \\
\text { refractory AML }\end{array}$ & $\mathrm{Ib}$ & - Recruiting \\
\hline Hu5F9-G4 +/- Azacitidine & $\begin{array}{l}\text { AML } \\
\text { MDS }\end{array}$ & $\begin{array}{l}\text { NCT03248479-trial of Hu5F9-G4 } \\
\text { monotherapy or with azacytidine in } \\
\text { hematologic malignancies }\end{array}$ & I & - Recruiting \\
\hline Hu5F9-G4 + Rituximab & NHL & $\begin{array}{l}\text { NCT02953509-trial of Hu5F9 with rituximab } \\
\text { in relapsed/refractory NHL }\end{array}$ & $\mathrm{Ib} / \mathrm{II}$ & $\begin{array}{l}\text { - Recruiting } \\
\text { - Hu5F9-G5 plus rituximab showed } \\
\text { promising activity in NHL patients } \\
\text { with no clinically significant safety } \\
\text { events [97]. }\end{array}$ \\
\hline $\begin{array}{l}\text { Hu5F9-G4 + Rituximab + } \\
\text { Acalabrutinib }\end{array}$ & NHL & $\begin{array}{l}\text { NCT03527147_-PRISM: platform study for the } \\
\text { treatment of relapsed/refractory aggressive } \\
\text { NHL }\end{array}$ & I & - Recruiting \\
\hline CC-90002 & $\begin{array}{l}\text { AML } \\
\text { MDS }\end{array}$ & $\begin{array}{l}\text { NCT02641002-trial of CC- } 90002 \text { in patients } \\
\text { with AML or high risk MDS }\end{array}$ & I & $\begin{array}{l}\text { - Terminated } \\
\text { - Monotherapy did not show } \\
\text { encouraging profile for further } \\
\text { studies }\end{array}$ \\
\hline CC-90002 +/- Rituximab & $\begin{array}{l}\text { Solid and hematologic } \\
\text { tumors }\end{array}$ & $\begin{array}{l}\text { NCT02367196-trial of CC-90002 in patients } \\
\text { with advanced solid tumors and hematologic } \\
\text { malignancies }\end{array}$ & I & - Recruiting \\
\hline $\begin{array}{l}\text { TTI- } 621+/- \text { Rituximab or } \\
\text { Nivolumab }\end{array}$ & $\begin{array}{l}\text { Solid and hematologic } \\
\text { tumors }\end{array}$ & $\begin{array}{l}\text { NCT02663518 - trial of TTI- } 621 \text { alone or with } \\
\text { other agents for hematologic malignancies and } \\
\text { selected solid tumors }\end{array}$ & I & $\begin{array}{l}\text { - Recruiting } \\
\text { - TTI-621 showed therapeutic efficacy } \\
\text { for SS patients [98]. }\end{array}$ \\
\hline $\begin{array}{l}\text { ALX-148 +/- Pembrolizumab or } \\
\text { Trastuzumab or Rituximab }\end{array}$ & $\begin{array}{l}\text { Solid and hematologic } \\
\text { tumors }\end{array}$ & $\begin{array}{l}\text { NCT03013218-trial of ALX-148 in patients } \\
\text { with advanced solid tumors and lymphoma }\end{array}$ & I & - Recruiting \\
\hline
\end{tabular}

Abbreviations: AML—acute myeloid leukemia; MDS—myelodysplastic syndrome; NHL—Non-Hodgkin's lymphoma; SS—Sézary syndrome. 


\section{Conclusion and Perspective}

Immunotherapy targeting different innate or adaptive immune cells is extensively studied and many studies have proposed newer ways to stimulate the immune system alone or in combination with pre-existing therapies. Unfortunately, there is no single strategy that works for all tumor types and many differences exist between solid tumors and hematologic malignancies. This is likely related to the unique and diverse tumor microenvironment composition in different leukemia and lymphoma as well as the inherent immunogenicity of different subtypes of hematologic malignancies. It has become apparent now that strategies that focus on enhancing the antitumoral abilities of cytotoxic $\mathrm{T}$ lymphocytes (CTLs) is insufficient to achieve significant tumor clearance in leukemia, lymphoma and myeloma. Rather, intervention that targets the immunosuppressive TME must be used in conjunction with CTL activation. As we have summarized in this review, TAMs play a critical role in hematologic malignancies through different mechanisms (Figure 1). Thus, it represents an attractive target in designing immunotherapies and different ways of targeting TAMs in hematologic malignancies have been found to synergistically enhance response to chemotherapeutics or immunotherapeutics. However, elucidating the molecular mechanisms responsible for macrophage polarization, especially in the various diverse TMEs of hematologic malignancies is necessary to determine the most effective TAM-targeting approaches to improve immunotherapies. It would also be valuable to better identify the array of markers and immunosuppressive molecules of TAMs in different leukemia/lymphoma subtypes to better delineate this heterogeneous population of cells. Results from these studies will be clinically informative in the treatment of hematologic malignancies in the future.
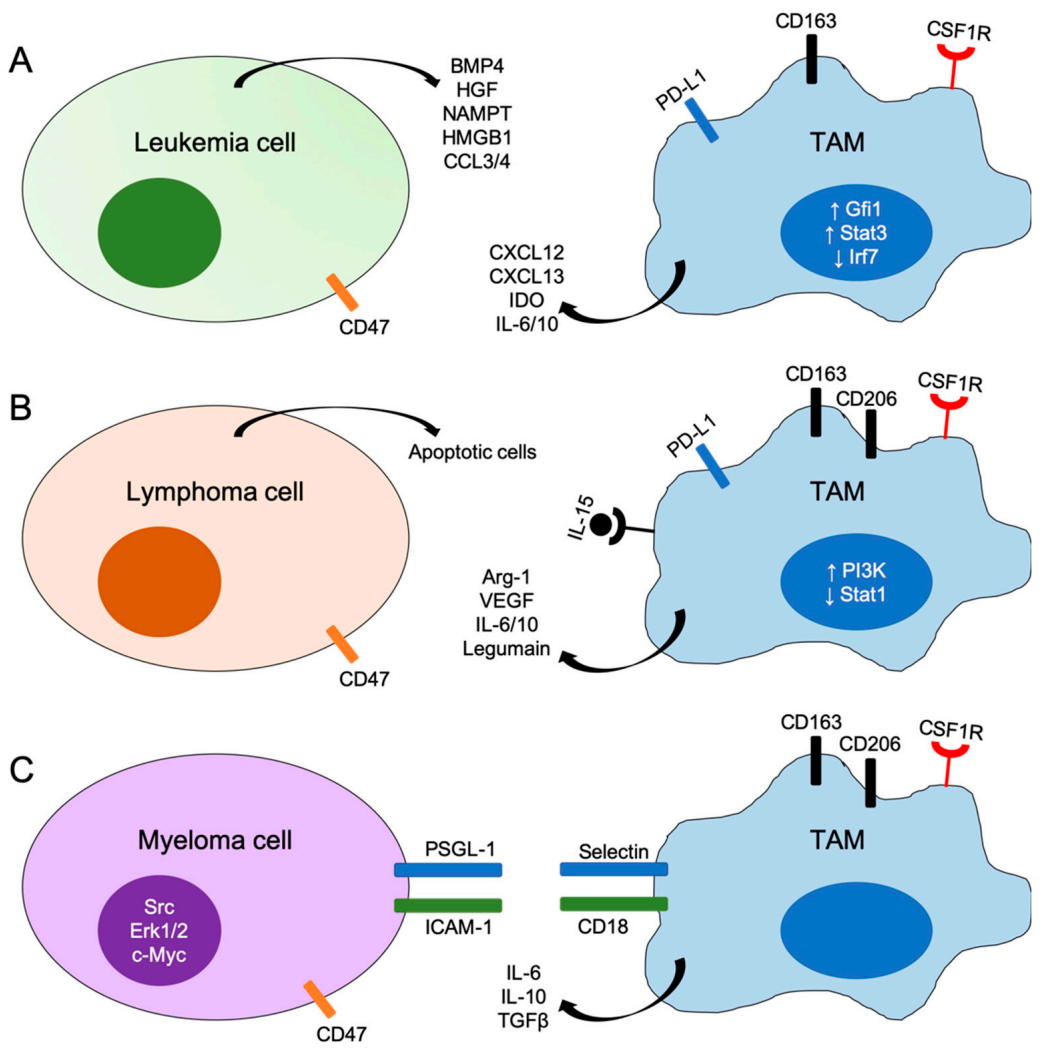

Figure 1. Schematic representations of mechanisms of interactions between tumor cells and tumor-associated macrophages (TAMs) in leukemia (A), lymphoma (B) and myeloma (C). $\mathrm{BMP} 4$, bone morphogenetic protein 4; HGF, hepatocyte growth factor; NAMPT, nicotinamide phosphoribosyltransferase; HMGB1, high mobility group box 1; IDO, indoleamine 2,3-dioxygenase; Arg-1, arginase-1; VEGF, vascular endothelial growth factor; PSGL-1, P-selectin glycoprotein ligand-1; ICAM-1, intercellular adhesion molecular-1; Gfi1, growth factor independent 1; Irf7, interferon regulatory factor 7; Stat, signal transducer and activator of transcription; CSF1R, colony stimulating factor 1 receptor. 
Author Contributions: A.J.P. and Y.Y. conceptualized the review, designed the figure and table and wrote the manuscript.

Funding: This work is supported by supported by National Institutes of Health grants CA136934, CA186973, CA193167 (to Y.Y.) and CA213799 (to A.J.P.).

Conflicts of Interest: The authors have no financial or non-financial conflicts of interest to disclose.

\section{References}

1. Qian, B.Z.; Pollard, J.W. Macrophage diversity enhances tumor progression and metastasis. Cell 2010, 141, 39-51. [CrossRef] [PubMed]

2. Biswas, S.K.; Mantovani, A. Macrophage plasticity and interaction with lymphocyte subsets: Cancer as a paradigm. Nat. Immunol. 2010, 11, 889-896. [CrossRef] [PubMed]

3. Quail, D.F.; Joyce, J.A. Microenvironmental regulation of tumor progression and metastasis. Nat. Med. 2013, 19, 1423-1437. [CrossRef] [PubMed]

4. Galletti, G.; Caligaris-Cappio, F.; Bertilaccio, M.T. B cells and macrophages pursue a common path toward the development and progression of chronic lymphocytic leukemia. Leukemia 2016, 30, 2293-2301. [CrossRef]

5. Komohara, Y.; Niino, D.; Ohnishi, K.; Ohshima, K.; Takeya, M. Role of tumor-associated macrophages in hematological malignancies. Pathol. Int. 2015, 65, 170-176. [CrossRef]

6. Ginhoux, F.; Jung, S. Monocytes and macrophages: Developmental pathways and tissue homeostasis. Nat. Rev. Immunol. 2014, 14, 392-404. [CrossRef] [PubMed]

7. Sica, A.; Mantovani, A. Macrophage plasticity and polarization: In vivo veritas. J. Clin. Invest. 2012, 122, 787-795. [CrossRef]

8. Xue, J.; Schmidt, S.V.; Sander, J.; Draffehn, A.; Krebs, W.; Quester, I.; De Nardo, D.; Gohel, T.D.; Emde, M.; Schmidleithner, L.; et al. Transcriptome-based network analysis reveals a spectrum model of human macrophage activation. Immunity 2014, 40, 274-288. [CrossRef]

9. Mantovani, A.; Biswas, S.K.; Galdiero, M.R.; Sica, A.; Locati, M. Macrophage plasticity and polarization in tissue repair and remodelling. J. Pathol. 2013, 229, 176-185. [CrossRef]

10. Petty, A.J.; Yang, Y. Tumor-associated macrophages: Implications in cancer immunotherapy. Immunotherapy 2017, 9, 289-302. [CrossRef]

11. Linde, N.; Lederle, W.; Depner, S.; van Rooijen, N.; Gutschalk, C.M.; Mueller, M.M. Vascular endothelial growth factor-induced skin carcinogenesis depends on recruitment and alternative activation of macrophages. J. Pathol. 2012, 227, 17-28. [CrossRef]

12. Qian, B.Z.; Li, J.; Zhang, H.; Kitamura, T.; Zhang, J.; Campion, L.R.; Kaiser, E.A.; Snyder, L.A.; Pollard, J.W. CCL2 recruits inflammatory monocytes to facilitate breast-tumour metastasis. Nature 2011, 475, $222-225$. [CrossRef]

13. Wang, X.; Yang, X.; Tsai, Y.; Yang, L.; Chuang, K.H.; Keng, P.C.; Lee, S.O.; Chen, Y. IL-6 Mediates Macrophage Infiltration after Irradiation via Up-regulation of CCL2/CCL5 in Non-small Cell Lung Cancer. Radiat. Res. 2017, 187, 50-59. [CrossRef]

14. Xuan, W.; Qu, Q.; Zheng, B.; Xiong, S.; Fan, G.H. The chemotaxis of M1 and M2 macrophages is regulated by different chemokines. J. Leukoc. Biol. 2015, 97, 61-69. [CrossRef]

15. Noy, R.; Pollard, J.W. Tumor-associated macrophages: From mechanisms to therapy. Immunity 2014, 41, 49-61. [CrossRef]

16. Lawrence, T.; Natoli, G. Transcriptional regulation of macrophage polarization: Enabling diversity with identity. Nat. Rev. Immunol. 2011, 11, 750-761. [CrossRef]

17. Szebeni, G.J.; Vizler, C.; Kitajka, K.; Puskas, L.G. Inflammation and Cancer: Extra- and Intracellular Determinants of Tumor-Associated Macrophages as Tumor Promoters. Mediat. Inflamm. 2017, 2017, 9294018. [CrossRef]

18. Gong, D.; Shi, W.; Yi, S.J.; Chen, H.; Groffen, J.; Heisterkamp, N. TGFbeta signaling plays a critical role in promoting alternative macrophage activation. BMC Immunol. 2012, 13, 31. [CrossRef]

19. Hanna, A.; Metge, B.J.; Bailey, S.K.; Chen, D.; Chandrashekar, D.S.; Varambally, S.; Samant, R.S.; Shevde, L.A. Inhibition of Hedgehog signaling reprograms the dysfunctional immune microenvironment in breast cancer. OncoImmunology 2019, 8, 1548241. [CrossRef] 
20. Colegio, O.R.; Chu, N.Q.; Szabo, A.L.; Chu, T.; Rhebergen, A.M.; Jairam, V.; Cyrus, N.; Brokowski, C.E.; Eisenbarth, S.C.; Phillips, G.M.; et al. Functional polarization of tumour-associated macrophages by tumour-derived lactic acid. Nature 2014, 513, 559-563. [CrossRef]

21. Pham, L.V.; Pogue, E.; Ford, R.J. The Role of Macrophage/B-Cell Interactions in the Pathophysiology of B-Cell Lymphomas. Front. Oncol. 2018, 8, 147. [CrossRef]

22. Komohara, Y.; Niino, D.; Saito, Y.; Ohnishi, K.; Horlad, H.; Ohshima, K.; Takeya, M. Clinical significance of $\mathrm{CD}_{163^{+}}$tumor-associated macrophages in patients with adult T-cell leukemia/lymphoma. Cancer Sci. 2013, 104, 945-951. [CrossRef]

23. Hohtari, H.; Bruck, O.; Blom, S.; Turkki, R.; Sinisalo, M.; Kovanen, P.E.; Kallioniemi, O.; Pellinen, T.; Porkka, K.; Mustjoki, $\mathrm{S}$. Immune cell constitution in bone marrow microenvironment predicts outcome in adult ALL. Leukemia 2019, 33, 1570-1582. [CrossRef]

24. Chen, S.Y.; Yang, X.; Feng, W.L.; Liao, J.F.; Wang, L.N.; Feng, L.; Lin, Y.M.; Ren, Q.; Zheng, G.G. Organ-specific microenvironment modifies diverse functional and phenotypic characteristics of leukemia-associated macrophages in mouse T cell acute lymphoblastic leukemia. J. Immunol. 2015, 194, 2919-2929. [CrossRef]

25. Valencia, J.; L, M.F.-S.; Fraile-Ramos, A.; Sacedon, R.; Jimenez, E.; Vicente, A.; Varas, A. Acute Lymphoblastic Leukaemia Cells Impair Dendritic Cell and Macrophage Differentiation: Role of BMP4. Cells 2019, 8, 722. [CrossRef]

26. Saint Fleur-Lominy, S.; Maus, M.; Vaeth, M.; Lange, I.; Zee, I.; Suh, D.; Liu, C.; Wu, X.; Tikhonova, A.; Aifantis, I.; et al. STIM1 and STIM2 Mediate Cancer-Induced Inflammation in T Cell Acute Lymphoblastic Leukemia. Cell. Rep. 2018, 24, 3045-3060. [CrossRef]

27. Al-Matary, Y.S.; Botezatu, L.; Opalka, B.; Hones, J.M.; Lams, R.F.; Thivakaran, A.; Schutte, J.; Koster, R.; Lennartz, K.; Schroeder, T.; et al. Acute myeloid leukemia cells polarize macrophages towards a leukemia supporting state in a Growth factor independence 1 dependent manner. Haematologica 2016, 101, 1216-1227. [CrossRef]

28. Yang, X.; Feng, W.; Wang, R.; Yang, F.; Wang, L.; Chen, S.; Ru, Y.; Cheng, T.; Zheng, G. Repolarizing heterogeneous leukemia-associated macrophages with more M1 characteristics eliminates their pro-leukemic effects. Oncoimmunology 2018, 7, e1412910. [CrossRef]

29. Jiang, M.; Zhang, J.; Qian, L.; Miao, Y.; Song, W.; Liu, H.; Li, R. MOZ Forms an Autoregulatory Feedback Loop with miR-223 in AML and Monocyte/Macrophage Development. Science 2019, 11, 189-204. [CrossRef]

30. Burger, J.A.; Tsukada, N.; Burger, M.; Zvaifler, N.J.; Dell'Aquila, M.; Kipps, T.J. Blood-derived nurse-like cells protect chronic lymphocytic leukemia B cells from spontaneous apoptosis through stromal cell-derived factor-1. Blood 2000, 96, 2655-2663. [CrossRef]

31. Burkle, A.; Niedermeier, M.; Schmitt-Graff, A.; Wierda, W.G.; Keating, M.J.; Burger, J.A. Overexpression of the CXCR5 chemokine receptor, and its ligand, CXCL13 in B-cell chronic lymphocytic leukemia. Blood 2007, 110, 3316-3325. [CrossRef]

32. Tsukada, N.; Burger, J.A.; Zvaifler, N.J.; Kipps, T.J. Distinctive features of "nurselike" cells that differentiate in the context of chronic lymphocytic leukemia. Blood 2002, 99, 1030-1037. [CrossRef]

33. Boissard, F.; Fournie, J.J.; Laurent, C.; Poupot, M.; Ysebaert, L. Nurse like cells: Chronic lymphocytic leukemia associated macrophages. Leuk. Lymphoma 2015, 56, 1570-1572. [CrossRef]

34. Giannoni, P.; Pietra, G.; Travaini, G.; Quarto, R.; Shyti, G.; Benelli, R.; Ottaggio, L.; Mingari, M.C.; Zupo, S.; Cutrona, G.; et al. Chronic lymphocytic leukemia nurse-like cells express hepatocyte growth factor receptor (c-MET) and indoleamine 2,3-dioxygenase and display features of immunosuppressive type 2 skewed macrophages. Haematologica 2014, 99, 1078-1087. [CrossRef]

35. Hanna, B.S.; McClanahan, F.; Yazdanparast, H.; Zaborsky, N.; Kalter, V.; Rossner, P.M.; Benner, A.; Durr, C.; Egle, A.; Gribben, J.G.; et al. Depletion of CLL-associated patrolling monocytes and macrophages controls disease development and repairs immune dysfunction in vivo. Leukemia 2016, 30, 570-579. [CrossRef]

36. Audrito, V.; Serra, S.; Brusa, D.; Mazzola, F.; Arruga, F.; Vaisitti, T.; Coscia, M.; Maffei, R.; Rossi, D.; Wang, T.; et al. Extracellular nicotinamide phosphoribosyltransferase (NAMPT) promotes M2 macrophage polarization in chronic lymphocytic leukemia. Blood 2015, 125, 111-123. [CrossRef]

37. Galletti, G.; Scielzo, C.; Barbaglio, F.; Rodriguez, T.V.; Riba, M.; Lazarevic, D.; Cittaro, D.; Simonetti, G.; Ranghetti, P.; Scarfo, L.; et al. Targeting Macrophages Sensitizes Chronic Lymphocytic Leukemia to Apoptosis and Inhibits Disease Progression. Cell. Rep. 2016, 14, 1748-1760. [CrossRef] 
38. Jia, L.; Clear, A.; Liu, F.T.; Matthews, J.; Uddin, N.; McCarthy, A.; Hoxha, E.; Durance, C.; Iqbal, S.; Gribben, J.G. Extracellular HMGB1 promotes differentiation of nurse-like cells in chronic lymphocytic leukemia. Blood 2014, 123, 1709-1719. [CrossRef]

39. Burger, J.A.; Quiroga, M.P.; Hartmann, E.; Burkle, A.; Wierda, W.G.; Keating, M.J.; Rosenwald, A. High-level expression of the T-cell chemokines CCL3 and CCL4 by chronic lymphocytic leukemia B cells in nurselike cell cocultures and after BCR stimulation. Blood 2009, 113, 3050-3058. [CrossRef]

40. Gautam, S.; Fatehchand, K.; Elavazhagan, S.; Reader, B.F.; Ren, L.; Mo, X.; Byrd, J.C.; Tridandapani, S.; Butchar, J.P. Reprogramming Nurse-like Cells with Interferon gamma to Interrupt Chronic Lymphocytic Leukemia Cell Survival. J. Biol. Chem. 2016, 291, 14356-14362. [CrossRef]

41. Mulder, T.A.; Wahlin, B.E.; Osterborg, A.; Palma, M. Targeting the Immune Microenvironment in Lymphomas of B-Cell Origin: From Biology to Clinical Application. Cancers 2019, 11, 915. [CrossRef]

42. Steidl, C.; Lee, T.; Shah, S.P.; Farinha, P.; Han, G.; Nayar, T.; Delaney, A.; Jones, S.J.; Iqbal, J.; Weisenburger, D.D.; et al. Tumor-associated macrophages and survival in classic Hodgkin's lymphoma. N. Engl J. Med. 2010, 362, 875-885. [CrossRef]

43. Tan, K.L.; Scott, D.W.; Hong, F.; Kahl, B.S.; Fisher, R.I.; Bartlett, N.L.; Advani, R.H.; Buckstein, R.; Rimsza, L.M.; Connors, J.M.; et al. Tumor-associated macrophages predict inferior outcomes in classic Hodgkin lymphoma: A correlative study from the E2496 Intergroup trial. Blood 2012, 120, 3280-3287. [CrossRef]

44. Martin-Moreno, A.M.; Roncador, G.; Maestre, L.; Mata, E.; Jimenez, S.; Martinez-Torrecuadrada, J.L.; Reyes-Garcia, A.I.; Rubio, C.; Tomas, J.F.; Estevez, M.; et al. CSF1R Protein Expression in Reactive Lymphoid Tissues and Lymphoma: Its Relevance in Classical Hodgkin Lymphoma. PLoS ONE 2015, 10, e0125203. [CrossRef]

45. Guo, B.; Cen, H.; Tan, X.; Ke, Q. Meta-analysis of the prognostic and clinical value of tumor-associated macrophages in adult classical Hodgkin lymphoma. BMC Med. 2016, 14, 159. [CrossRef]

46. Carey, C.D.; Gusenleitner, D.; Lipschitz, M.; Roemer, M.G.M.; Stack, E.C.; Gjini, E.; Hu, X.; Redd, R.; Freeman, G.J.; Neuberg, D.; et al. Topological analysis reveals a PD-L1-associated microenvironmental niche for Reed-Sternberg cells in Hodgkin lymphoma. Blood 2017, 130, 2420-2430. [CrossRef]

47. Vari, F.; Arpon, D.; Keane, C.; Hertzberg, M.S.; Talaulikar, D.; Jain, S.; Cui, Q.; Han, E.; Tobin, J.; Bird, R.; et al. Immune evasion via PD-1/PD-L1 on NK cells and monocyte/macrophages is more prominent in Hodgkin lymphoma than DLBCL. Blood 2018, 131, 1809-1819. [CrossRef]

48. Locatelli, S.L.; Careddu, G.; Serio, S.; Consonni, F.M.; Maeda, A.; Viswanadha, S.; Vakkalanka, S.; Castagna, L.; Santoro, A.; Allavena, P.; et al. Targeting Cancer Cells and Tumor Microenvironment in Preclinical and Clinical Models of Hodgkin Lymphoma Using the Dual PI3Kdelta/gamma Inhibitor RP6530. Clin. Cancer Res. 2019, 25, 1098-1112. [CrossRef]

49. Farinha, P.; Masoudi, H.; Skinnider, B.F.; Shumansky, K.; Spinelli, J.J.; Gill, K.; Klasa, R.; Voss, N.; Connors, J.M.; Gascoyne, R.D. Analysis of multiple biomarkers shows that lymphoma-associated macrophage (LAM) content is an independent predictor of survival in follicular lymphoma (FL). Blood 2005, 106, 2169-2174. [CrossRef]

50. Canioni, D.; Salles, G.; Mounier, N.; Brousse, N.; Keuppens, M.; Morchhauser, F.; Lamy, T.; Sonet, A.; Rousselet, M.C.; Foussard, C.; et al. High numbers of tumor-associated macrophages have an adverse prognostic value that can be circumvented by rituximab in patients with follicular lymphoma enrolled onto the GELA-GOELAMS FL-2000 trial. J. Clin. Oncol. 2008, 26, 440-446. [CrossRef]

51. Clear, A.J.; Lee, A.M.; Calaminici, M.; Ramsay, A.G.; Morris, K.J.; Hallam, S.; Kelly, G.; Macdougall, F.; Lister, T.A.; Gribben, J.G. Increased angiogenic sprouting in poor prognosis FL is associated with elevated numbers of $\mathrm{CD} 63^{+}$macrophages within the immediate sprouting microenvironment. Blood 2010, 115, 5053-5056. [CrossRef]

52. Voss, J.; Ford, C.A.; Petrova, S.; Melville, L.; Paterson, M.; Pound, J.D.; Holland, P.; Giotti, B.; Freeman, T.C.; Gregory, C.D. Modulation of macrophage antitumor potential by apoptotic lymphoma cells. Cell Death Differ. 2017, 24, 971-983. [CrossRef]

53. Guilloton, F.; Caron, G.; Menard, C.; Pangault, C.; Ame-Thomas, P.; Dulong, J.; De Vos, J.; Rossille, D.; Henry, C.; Lamy, T.; et al. Mesenchymal stromal cells orchestrate follicular lymphoma cell niche through the CCL2-dependent recruitment and polarization of monocytes. Blood 2012, 119, 2556-2567. [CrossRef] [PubMed] 
54. Epron, G.; Ame-Thomas, P.; Le Priol, J.; Pangault, C.; Dulong, J.; Lamy, T.; Fest, T.; Tarte, K. Monocytes and T cells cooperate to favor normal and follicular lymphoma B-cell growth: Role of IL-15 and CD40L signaling. Leukemia 2012, 26, 139-148. [CrossRef] [PubMed]

55. Lenz, G.; Wright, G.; Dave, S.S.; Xiao, W.; Powell, J.; Zhao, H.; Xu, W.; Tan, B.; Goldschmidt, N.; Iqbal, J.; et al. Stromal gene signatures in large-B-cell lymphomas. N. Engl. J. Med. 2008, 359, 2313-2323. [CrossRef]

56. Monti, S.; Savage, K.J.; Kutok, J.L.; Feuerhake, F.; Kurtin, P.; Mihm, M.; Wu, B.; Pasqualucci, L.; Neuberg, D.; Aguiar, R.C.; et al. Molecular profiling of diffuse large B-cell lymphoma identifies robust subtypes including one characterized by host inflammatory response. Blood 2005, 105, 1851-1861. [CrossRef]

57. Azzaoui, I.; Uhel, F.; Rossille, D.; Pangault, C.; Dulong, J.; Le Priol, J.; Lamy, T.; Houot, R.; Le Gouill, S.; Cartron, G.; et al. T-cell defect in diffuse large B-cell lymphomas involves expansion of myeloid-derived suppressor cells. Blood 2016, 128, 1081-1092. [CrossRef]

58. Marmey, B.; Boix, C.; Barbaroux, J.B.; Dieu-Nosjean, M.C.; Diebold, J.; Audouin, J.; Fridman, W.H.; Mueller, C.G.; Molina, T.J. CD14 and CD169 expression in human lymph nodes and spleen: Specific expansion of $\mathrm{CD} 14^{+} \mathrm{CD} 169^{-}$monocyte-derived cells in diffuse large B-cell lymphomas. Hum. Pathol. 2006, 37, 68-77. [CrossRef]

59. Wang, J.; Gao, K.; Lei, W.; Dong, L.; Xuan, Q.; Feng, M.; Wang, J.; Ye, X.; Jin, T.; Zhang, Z.; et al. Lymphocyte-to-monocyte ratio is associated with prognosis of diffuse large B-cell lymphoma: Correlation with CD163 positive M2 type tumor-associated macrophages, not PD-1 positive tumor-infiltrating lymphocytes. Oncotarget 2017, 8, 5414-5425. [CrossRef]

60. Marchesi, F.; Cirillo, M.; Bianchi, A.; Gately, M.; Olimpieri, O.M.; Cerchiara, E.; Renzi, D.; Micera, A.; Balzamino, B.O.; Bonini, S.; et al. High density of CD68+/CD163+ tumour-associated macrophages (M2-TAM) at diagnosis is significantly correlated to unfavorable prognostic factors and to poor clinical outcomes in patients with diffuse large B-cell lymphoma. Hematol. Oncol. 2015, 33, 110-112. [CrossRef]

61. Nam, S.J.; Kim, S.; Kwon, D.; Kim, H.; Kim, S.; Lee, E.; Kim, T.M.; Heo, D.S.; Park, S.H.; Lim, M.S.; et al. Prognostic implications of tumor-infiltrating macrophages, M2 macrophages, regulatory T-cells, and indoleamine 2,3-dioxygenase-positive cells in primary diffuse large B-cell lymphoma of the central nervous system. Oncoimmunology 2018, 7, e1442164. [CrossRef] [PubMed]

62. Li, Y.-L.; Shi, Z.-H.; Wang, X.; Gu, K.-S.; Zhai, Z.-M. Tumor-associated macrophages predict prognosis in diffuse large B-cell lymphoma and correlation with peripheral absolute monocyte count. BMC Cancer 2019, 19, 1049. [CrossRef] [PubMed]

63. Kawajiri, A.; Kitano, S.; Maeshima, A.M.; Inamoto, Y.; Tajima, K.; Takemura, T.; Tanaka, T.; Ito, A.; Okinaka, K.; Kurosawa, S.; et al. Association of CD204 ${ }^{+}$macrophages with poor outcomes of malignant lymphomas not in remission treated by allogeneic HCT. Eur. J. Haematol. 2019, 103, 578-587. [CrossRef] [PubMed]

64. Lin, Y.; Gustafson, M.P.; Bulur, P.A.; Gastineau, D.A.; Witzig, T.E.; Dietz, A.B. Immunosuppressive CD14 ${ }^{+}$HLA-DR ${ }^{\text {low/- }}$ monocytes in B-cell non-Hodgkin lymphoma. Blood 2011, 117, 872-881. [CrossRef]

65. Xiu, B.; Lin, Y.; Grote, D.M.; Ziesmer, S.C.; Gustafson, M.P.; Maas, M.L.; Zhang, Z.; Dietz, A.B.; Porrata, L.F.; Novak, A.J.; et al. IL-10 induces the development of immunosuppressive CD14 ${ }^{+} \mathrm{HLA}-\mathrm{DR}{ }^{\text {low } /-}$ monocytes in B-cell non-Hodgkin lymphoma. Blood Cancer J. 2015, 5, e328. [CrossRef]

66. Shen, L.; Li, H.; Shi, Y.; Wang, D.; Gong, J.; Xun, J.; Zhou, S.; Xiang, R.; Tan, X. M2 tumour-associated macrophages contribute to tumour progression via legumain remodelling the extracellular matrix in diffuse large B cell lymphoma. Sci. Rep. 2016, 6, 30347. [CrossRef]

67. Zheng, Y.; Cai, Z.; Wang, S.; Zhang, X.; Qian, J.; Hong, S.; Li, H.; Wang, M.; Yang, J.; Yi, Q. Macrophages are an abundant component of myeloma microenvironment and protect myeloma cells from chemotherapy drug-induced apoptosis. Blood 2009, 114, 3625-3628. [CrossRef]

68. Kim, J.; Denu, R.A.; Dollar, B.A.; Escalante, L.E.; Kuether, J.P.; Callander, N.S.; Asimakopoulos, F.; Hematti, P. Macrophages and mesenchymal stromal cells support survival and proliferation of multiple myeloma cells. Br. J. Haematol. 2012, 158, 336-346. [CrossRef]

69. Kfir-Erenfeld, S.; Sionov, R.V.; Spokoini, R.; Cohen, O.; Yefenof, E. Protein kinase networks regulating glucocorticoid-induced apoptosis of hematopoietic cancer cells: Fundamental aspects and practical considerations. Leuk. Lymphoma 2010, 51, 1968-2005. [CrossRef]

70. Podar, K.; Anderson, K.C. A therapeutic role for targeting c-Myc/Hif-1-dependent signaling pathways. Cell Cycle 2010, 9, 1722-1728. [CrossRef] 
71. Suyani, E.; Sucak, G.T.; Akyurek, N.; Sahin, S.; Baysal, N.A.; Yagci, M.; Haznedar, R. Tumor-associated macrophages as a prognostic parameter in multiple myeloma. Ann. Hematol. 2013, 92, 669-677. [CrossRef] [PubMed]

72. Panchabhai, S.; Kelemen, K.; Ahmann, G.; Sebastian, S.; Mantei, J.; Fonseca, R. Tumor-associated macrophages and extracellular matrix metalloproteinase inducer in prognosis of multiple myeloma. Leukemia 2016, 30, 951-954. [CrossRef] [PubMed]

73. Andersen, M.N.; Andersen, N.F.; Rodgaard-Hansen, S.; Hokland, M.; Abildgaard, N.; Moller, H.J. The novel biomarker of alternative macrophage activation, soluble mannose receptor (sMR/sCD206): Implications in multiple myeloma. Leuk. Res. 2015, 39, 971-975. [CrossRef] [PubMed]

74. Wang, H.; Hu, W.M.; Xia, Z.J.; Liang, Y.; Lu, Y.; Lin, S.X.; Tang, H. High numbers of CD163+ tumor-associated macrophages correlate with poor prognosis in multiple myeloma patients receiving bortezomib-based regimens. J. Cancer 2019, 10, 3239-3245. [CrossRef] [PubMed]

75. Polk, A.; Lu, Y.; Wang, T.; Seymour, E.; Bailey, N.G.; Singer, J.W.; Boonstra, P.S.; Lim, M.S.; Malek, S.; Wilcox, R.A. Colony-Stimulating Factor-1 Receptor Is Required for Nurse-like Cell Survival in Chronic Lymphocytic Leukemia. Clin. Cancer Res. 2016, 22, 6118-6128. [CrossRef]

76. Edwards, D.K.T.; Watanabe-Smith, K.; Rofelty, A.; Damnernsawad, A.; Laderas, T.; Lamble, A.; Lind, E.F.; Kaempf, A.; Mori, M.; Rosenberg, M.; et al. CSF1R inhibitors exhibit antitumor activity in acute myeloid leukemia by blocking paracrine signals from support cells. Blood 2019, 133, 588-599. [CrossRef]

77. Wang, Q.; Lu, Y.; Li, R.; Jiang, Y.; Zheng, Y.; Qian, J.; Bi, E.; Zheng, C.; Hou, J.; Wang, S.; et al. Therapeutic effects of CSF1R-blocking antibodies in multiple myeloma. Leukemia 2018, 32, 176-183. [CrossRef]

78. Papin, A.; Tessoulin, B.; Bellanger, C.; Moreau, A.; Le Bris, Y.; Maisonneuve, H.; Moreau, P.; Touzeau, C.; Amiot, M.; Pellat-Deceunynck, C.; et al. CSF1R and BTK inhibitions as novel strategies to disrupt the dialog between mantle cell lymphoma and macrophages. Leukemia 2019. [CrossRef]

79. Edwards, V.D.; Sweeney, D.T.; Ho, H.; Eide, C.A.; Rofelty, A.; Agarwal, A.; Liu, S.Q.; Danilov, A.V.; Lee, P.; Chantry, D.; et al. Targeting of colony-stimulating factor 1 receptor (CSF1R) in the CLL microenvironment yields antineoplastic activity in primary patient samples. Oncotarget 2018, 9, 24576-24589. [CrossRef]

80. Germano, G.; Frapolli, R.; Simone, M.; Tavecchio, M.; Erba, E.; Pesce, S.; Pasqualini, F.; Grosso, F.; Sanfilippo, R.; Casali, P.G.; et al. Antitumor and anti-inflammatory effects of trabectedin on human myxoid liposarcoma cells. Cancer Res. 2010, 70, 2235-2244. [CrossRef]

81. Germano, G.; Frapolli, R.; Belgiovine, C.; Anselmo, A.; Pesce, S.; Liguori, M.; Erba, E.; Uboldi, S.; Zucchetti, M.; Pasqualini, F; et al. Role of macrophage targeting in the antitumor activity of trabectedin. Cancer Cell. 2013, 23, 249-262. [CrossRef] [PubMed]

82. Asimakopoulos, F.; Kim, J.; Denu, R.A.; Hope, C.; Jensen, J.L.; Ollar, S.J.; Hebron, E.; Flanagan, C.; Callander, N.; Hematti, P. Macrophages in multiple myeloma: Emerging concepts and therapeutic implications. Leuk. Lymphoma 2013, 54, 2112-2121. [CrossRef] [PubMed]

83. Chanan-Khan, A.A.; Cheson, B.D. Lenalidomide for the treatment of B-cell malignancies. J. Clin. Oncol. 2008, 26, 1544-1552. [CrossRef] [PubMed]

84. Schulz, A.; Durr, C.; Zenz, T.; Dohner, H.; Stilgenbauer, S.; Lichter, P.; Seiffert, M. Lenalidomide reduces survival of chronic lymphocytic leukemia cells in primary cocultures by altering the myeloid microenvironment. Blood 2013, 121, 2503-2511. [CrossRef] [PubMed]

85. Vo, M.C.; Jung, S.H.; Chu, T.H.; Lee, H.J.; Lakshmi, T.J.; Park, H.S.; Kim, H.J.; Rhee, J.H.; Lee, J.J. Lenalidomide and Programmed Death-1 Blockade Synergistically Enhances the Effects of Dendritic Cell Vaccination in a Model of Murine Myeloma. Front. Immunol. 2018, 9, 1370. [CrossRef] [PubMed]

86. Witzig, T.E.; Luigi Zinzani, P.; Habermann, T.M.; Tuscano, J.M.; Drach, J.; Ramchandren, R.; Kalayoglu Besisik, S.; Takeshita, K.; Casadebaig Bravo, M.L.; Zhang, L.; et al. Long-term analysis of phase II studies of single-agent lenalidomide in relapsed/refractory mantle cell lymphoma. Am. J. Hematol. 2017, 92, E575-E583. [CrossRef]

87. Tilly, H.; Morschhauser, F.; Casasnovas, O.; Molina, T.J.; Feugier, P.; Gouill, S.L.; Haioun, C.; Tournilhac, O.; Bouabdallah, R.; Gabarre, J.; et al. Lenalidomide in combination with R-CHOP (R2-CHOP) as first-line treatment of patients with high tumour burden follicular lymphoma: A single-arm, open-label, phase 2 study. Lancet Haematol. 2018, 5, e403-e410. [CrossRef] 
88. Leonard, J.P.; Trneny, M.; Izutsu, K.; Fowler, N.H.; Hong, X.; Zhu, J.; Zhang, H.; Offner, F.; Scheliga, A.; Nowakowski, G.S.; et al. AUGMENT: A Phase III Study of Lenalidomide Plus Rituximab Versus Placebo Plus Rituximab in Relapsed or Refractory Indolent Lymphoma. J. Clin. Oncol. 2019, 37, 1188-1199. [CrossRef]

89. Zucca, E.; Rondeau, S.; Vanazzi, A.; Ostenstad, B.; Mey, U.J.M.; Rauch, D.; Wahlin, B.E.; Hitz, F.; Hernberg, M.; Johansson, A.S.; et al. Short regimen of rituximab plus lenalidomide in follicular lymphoma patients in need of first-line therapy. Blood 2019, 134, 353-362. [CrossRef]

90. Feng, M.; Jiang, W.; Kim, B.Y.S.; Zhang, C.C.; Fu, Y.X.; Weissman, I.L. Phagocytosis checkpoints as new targets for cancer immunotherapy. Nat. Rev. Cancer 2019. [CrossRef]

91. Jaiswal, S.; Jamieson, C.H.; Pang, W.W.; Park, C.Y.; Chao, M.P.; Majeti, R.; Traver, D.; van Rooijen, N.; Weissman, I.L. CD47 is upregulated on circulating hematopoietic stem cells and leukemia cells to avoid phagocytosis. Cell 2009, 138, 271-285. [CrossRef] [PubMed]

92. Majeti, R.; Chao, M.P.; Alizadeh, A.A.; Pang, W.W.; Jaiswal, S.; Gibbs, K.D., Jr.; van Rooijen, N.; Weissman, I.L. CD47 is an adverse prognostic factor and therapeutic antibody target on human acute myeloid leukemia stem cells. Cell 2009, 138, 286-299. [CrossRef]

93. Kim, D.; Wang, J.; Willingham, S.B.; Martin, R.; Wernig, G.; Weissman, I.L. Anti-CD47 antibodies promote phagocytosis and inhibit the growth of human myeloma cells. Leukemia 2012, 26, 2538-2545. [CrossRef] [PubMed]

94. Liu, X.; Pu, Y.; Cron, K.; Deng, L.; Kline, J.; Frazier, W.A.; Xu, H.; Peng, H.; Fu, Y.X.; Xu, M.M. CD47 blockade triggers T cell-mediated destruction of immunogenic tumors. Nat. Med. 2015, 21, 1209-1215. [CrossRef] [PubMed]

95. Piccione, E.C.; Juarez, S.; Liu, J.; Tseng, S.; Ryan, C.E.; Narayanan, C.; Wang, L.; Weiskopf, K.; Majeti, R. A bispecific antibody targeting CD47 and CD20 selectively binds and eliminates dual antigen expressing lymphoma cells. MAbs 2015, 7, 946-956. [CrossRef] [PubMed]

96. Folkes, A.S.; Feng, M.; Zain, J.M.; Abdulla, F.; Rosen, S.T.; Querfeld, C. Targeting CD47 as a cancer therapeutic strategy: The cutaneous T-cell lymphoma experience. Curr. Opin. Oncol. 2018, 30, 332-337. [CrossRef]

97. Advani, R.; Flinn, I.; Popplewell, L.; Forero, A.; Bartlett, N.L.; Ghosh, N.; Kline, J.; Roschewski, M.; LaCasce, A.; Collins, G.P.; et al. CD47 Blockade by Hu5F9-G4 and Rituximab in Non-Hodgkin's Lymphoma. N. Engl. J. Med. 2018, 379, 1711-1721. [CrossRef]

98. Johnson, L.D.S.; Banerjee, S.; Kruglov, O.; Viller, N.N.; Horwitz, S.M.; Lesokhin, A.; Zain, J.; Querfeld, C.; Chen, R.; Okada, C.; et al. Targeting CD47 in Sezary syndrome with SIRPalphaFc. Blood Adv. 2019, 3, 1145-1153. [CrossRef]

99. Brierley, C.K.; Staves, J.; Roberts, C.; Johnson, H.; Vyas, P.; Goodnough, L.T.; Murphy, M.F. The effects of monoclonal anti-CD47 on RBCs, compatibility testing, and transfusion requirements in refractory acute myeloid leukemia. Transfusion 2019, 59, 2248-2254. [CrossRef] 